\title{
A „JÁRÓ-TÁBLA” (AVAGY AZ EGYES TERMÖHELYTÍPUSOKON ALKALMAZHATÓ CÉLÁLLOMÁNYOK ÉS AZOK NÖVEKEDÉSÉNEK) KÖZELÍTÉSE GÉPI TANULÁSI MÓDSZERREL
}

\author{
Czimber Kornél', Mátyás Csaba², Bidló András² és Gálos Borbálaª \\ ${ }^{1}$ Soproni Egyetem, Geomatikai, Erdőfeltárási és Vizgazdálkodási Intézet \\ ${ }^{2}$ Soproni Egyetem, Környezet és Földtudományi Intézet
}

\begin{abstract}
Kivonat
Ebben a cikkben egy gépi tanulási eljárást kivánunk bemutatni, amely a Járó-féle egyes termőhelytípusokon alkalmazható célállományok és azok növekedésének adatait dolgozza fel. A módszer képes a meglévő adatok alapján célállomány és növekedést javasolni a klímaváltozás miatt kialakuló új termőhelytípus változatokra, és egy újonnan belépő erdészeti klímaosztályra is. Az eljárás lényege, hogy a Járó-tábla bejegyzéseit egy ötdimenziós térben helyezi el és távolság kernelek segítségével kiválogatja a közeli célállomány típusokat, valamint súlyozza azok növekedését. Ezáltal megadja egy kiválasztott termöhelytipus változatra, hogy mely célállományok valószínüsíthetők azon a területen és milyen növekedéssel jellemezhetök. Az eredmények megfelelö validálás után az Agrárklíma projekt döntéstámogató rendszerébe épülnek be.
\end{abstract}

Kulcsszavak: gépi tanulás, termöhely, célállomány, növekedés.

\section{MACHINE LEARNING APPROXIMATION OF JÁRÓ-TABLE (TABLE OF APPLICABLE TARGETED FOREST STANDS AND THEIR GROWTH FOR EACH FOREST SITE)}

\begin{abstract}
In this article, we would like to present a machine learning algorithm that processes the data of Járó's target stands and their growth for each forest site variation. The method is able to propose stand types and growths on the basis of existing data for new variations due to climate change and for a newly entering forest climate zone. The essence of this process is to place the entries of the Járó's table in a five-dimensional space, and use distance kernels to select the closest target stand types and weight their growth rate. It defines for a specific forest site, which target stands are likely to be in the area and what kind of growth can be characterized. The results will be incorporated into the decision support system of the Agrárklima project after proper validation.
\end{abstract}

Keywords: machine learning, forest site, targeted stand, growth. 


\section{BEVEZETÉS}

A klímaváltozás erdőgazdálkodást befolyásoló magyarországi hatásaival, fontossága miatt számos publikáció foglalkozott az elmúlt időszakban (Mátyás \& Czimber 2000, 2004; Berki et al. 2009; Rasztovits et al. 2014; Gálos et al. 2015). A nemzetközi szakirodalom rámutat, hogy a komplex probléma feldolgozása, tekintettel a nagy mennyiségü térbeli és időbeli adatokra, csak döntéstámogató rendszerek segítségével valósitható meg hatékonyan (Ray 2001; Falcão \& Borges 2005; Reynolds et al. 2008; Vacik et al. 2010).

Az Agrárklíma projekt keretében fejlesztett döntéstámogató rendszer (eDTR) egyik legfontosabb célkitüzése az integrált geoinformatikai és klímamodellek adatai alapján becslést adni több jövőbeli időszakban az alkalmazható célállományokra és azok növekedésére (Czimber \& Gálos 2016). Járó Zoltán és munkatársai által kidolgozott és évtizedek óta alkalmazott, az elmúlt évtizedben továbbfejlesztett táblázat (Balogh et al. 2005), továbbiakban Járó-tábla (1. ábra), termőhelytípus-változatonként tartalmazza az alkalmazható célállományokat, a föfafajokat és azok növekedését, valamint az elegyfajokat.

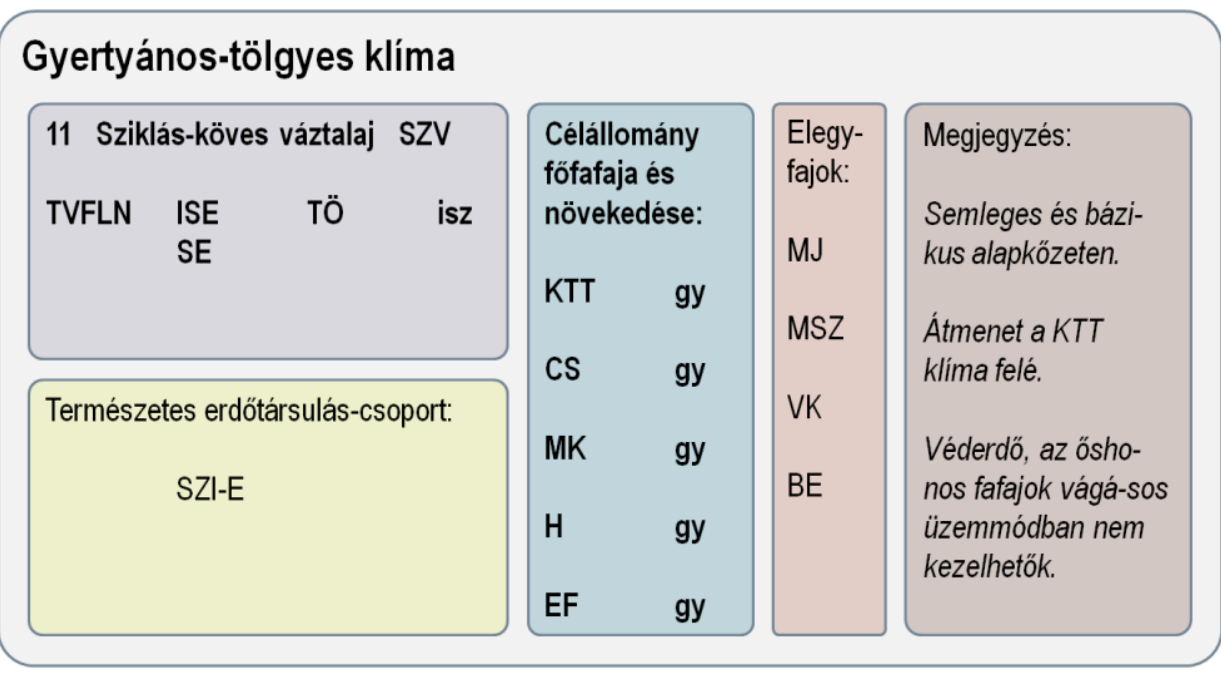

1. ábra: Járó-tábla részlete egy termőhelytípus-változatra.

Figure 1: Járó-table for one forest site variation.

Az eDTR fejlesztésénél számos kihivásnak kellett megfelelni. A geoadatok integrációja több problémát felvetett. A jövőbeli időszak klímáját elörejelző 12 regionális klímamodell adatait a jóval finomabb felbontású múltbeli klímaadatokkal kellett összehangolni és javítani. Kísérletek folynak a klímaadatok javítására a domborzat és kitettség alapján, mivel a múltbeli modellek felbontása $10 \mathrm{~km}$, a jövőbeli modelleké közelítőleg $25 \mathrm{~km}$-es. A termőhelytípusváltozat talaj és hidrológiai adatait is több forrásból pontosítottuk. 
Az eDTR ezeket a geoadatokat és a Járó-tábla mintegy 5 ezer termőhelytípus-változat fafaj - növekedés bejegyzését használja fel a jövőbeli erdőtelepítési és erdőfelújitási döntések támogatásához. Azonban a klímaváltozás, amely általában egy, ritkábban két erdészeti klímaosztály változást is jelenthet a következő évtizedekben egészen 2100-ig, számos olyan új termőhelytípus-változatot eredményez, amely az eddigi Járó-táblában nem szerepel.

A hiányok kitöltésére kidolgoztunk egy gépi tanulási módszert, amely a Járó-tábla adataiból indul ki, azok adataiból tanul, és a tanulási folyamat végén becslést ad a növekedésre.

\section{ANYAG ÉS MÓDSZER}

A módszer kifejlesztéséhez a Járó tábla 2005-ös változatán kívül felhasználtuk tizenkét klímamodell adatait (Czimber \& Gálos 2016), az erdőállomány adattár erdőrészlet és termőhelytípus-változat adatait. A Járó tábla jó-közepes-gyenge növekedését rendre 3, 2, 1 értékekkel helyettesítettük, tehát a magasabb érték jelenti a jobb növekedést, ezt az értékek kvantifikálása miatt vezettük be. Ahol a Járó táblában egy célállomány növekedésénél két kategória is szerepel, ott az átlagértéket használtunk (1,5 és 2,5).

A módszer előzetes változatában külön próbáltuk modellezni az egyes termőhelyi tényezők függvényében a növekedést (2. ábra). A hidrológia és a genetikai talajtípus esetén maradtunk a kategóriáknál.
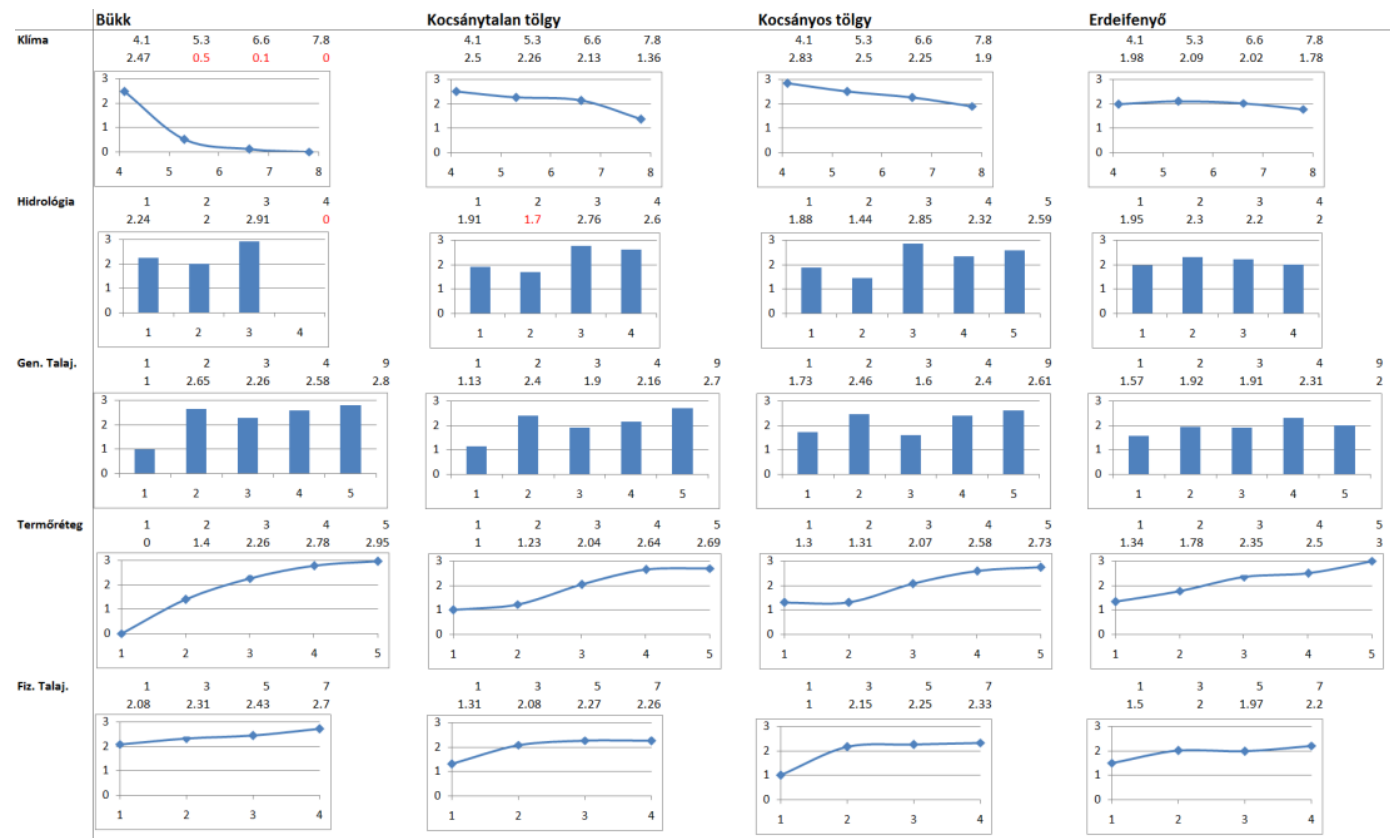

2. ábra: Négy célállomány 5 termőhelyi paraméterének növekedési görbéi.

Figure 2: Growing functions for 5 forest site parameter of 4 targeted stands. 
Az egydimenziós megközelítésnél pontosabb modellezést biztosítanak a kétparaméteres (3. ábra) vagy több-, maximum ötparaméteres függvények. A végleges módszernél az utóbbit választottuk.

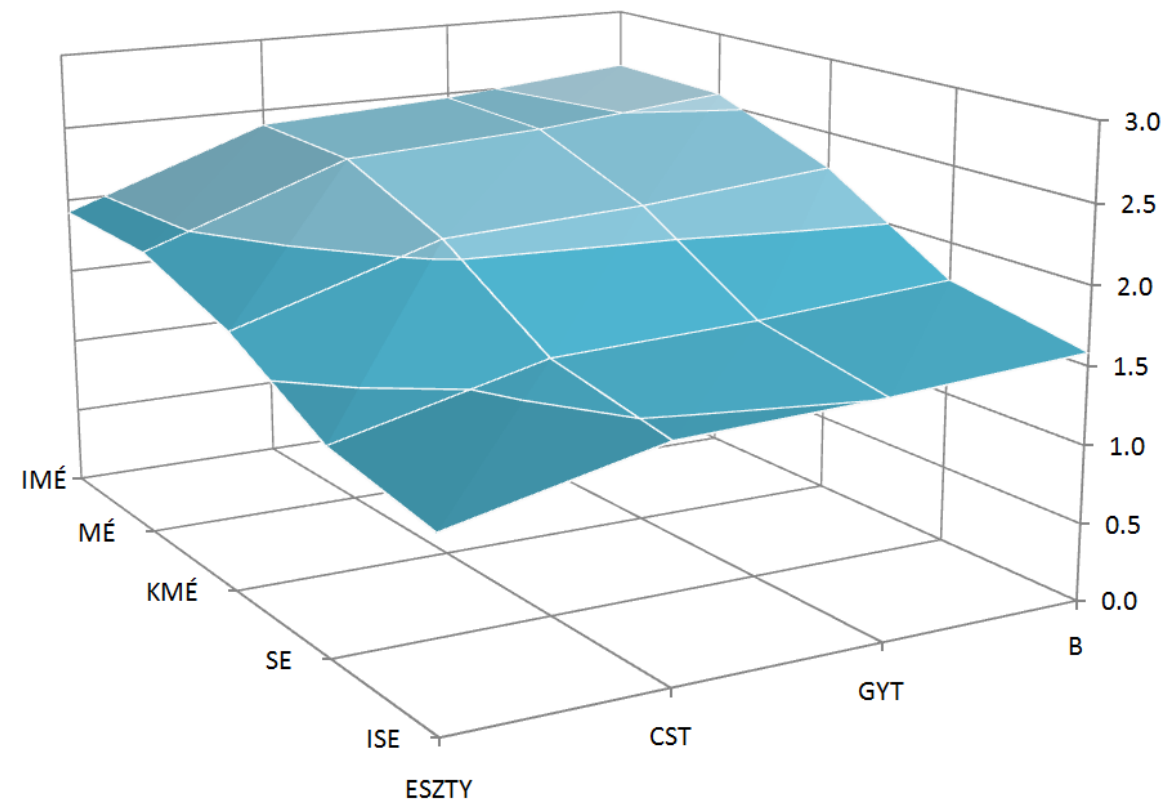

3. ábra: KTT növekedése az erdészeti klímaosztály és a termöréteg vastagság függvényében. Figure 3: Growth of Sessile Oak by forest climate zone and soil thickness.

A módszer fejlesztésének első lépéseként megpróbáltuk valamennyi termőhelytípus-változat tényezőt mennyiségi értékekre váltani. A klímaosztály esetében a FAI (Forest Aridity Index) (Führer 2010; Führer et al. 2011), a termöréteg vastagság esetében a konkrét mélység, a fizikai talajéleségnél a víztartó képességgel helyettesítettük a kategóriákat. A genetikai talajtípus és hidrológiai viszonyok tekintetében megtartottuk a kategóriákat, nagyobb súlyt rendelve ezekhez a tényezökhöz, hogy az egyes kategóriák ne mosódjanak össze. Első körben csak a többletvízhatástól-független termöhelyekkel foglalkoztunk.

A gépi tanulási módszer a kvantifikált adatok alapján egy ötdimenziós termőhelytípusváltozat térben keresi a legközelebbi célállományokat és kernelek segítségével súlyozza azok növekedését. Távolsággal fordítottan arányos súlyozást távolságkernelek segítségével oldottuk meg. Minden egyes Járó tábla bejegyzéshez egy ötdimenziós kernel tartozik, amely a távolodva a bejegyzéstöl a kernel értéke fokozatosan 1-röl nullára csökken. A módszer a több dimenziós adatok lokális becslésénél gyakran alkalmazott kernel sürüség eljáráson alapul (Rosenblatt 1956; Silverman 1986). Távolságkernelnek a Gauss-kernelt választottuk. 
Az $f$ növekedés becslése $c$ célállományra, $T$ termőhelyre a $J$ Járótábla bejegyzési alapján, $n$ növekedésadatokra a következő képlettel történik, ahol $i$ valamennyi Járó tábla bejegyzés indexe, $t$ a termőhelyi paraméter indexe, $q t$ konstans a távolságkernel szélességét befolyásolja termőhelyi paraméterenként, e a természetes alapú logaritmus alapszáma:

$$
f_{c}(T)=\sum_{i=1}^{p} \sum_{t=1}^{5} n_{c i} e^{q_{t}\left(T_{t}-J_{c i t}\right)}
$$

Az elöbbi képletből az $n$ növekedés értékek elhagyásával jutunk a távolság kernel képletéhez, a súlyozott növekedésértéket ezzel kell normalizálni:

$$
w_{c}(T)=\sum_{i=1}^{p} \sum_{t=1}^{5} e^{q_{t}\left(T_{t}-J_{c i t}\right)}
$$

Az előbbi két képlettel a növekedési értékek súlyozhatók tetszőleges számú paraméter felhasználásával (4. ábra, Interpolált görbe). Ez egy tényező esetén egy görbét, öt tényező esetén egy hiperfelületet eredményez, mely jól követi a kiindulási adatokat (4. ábra, Input), és extrapoláció esetén a szélső értékeket veszi fel.

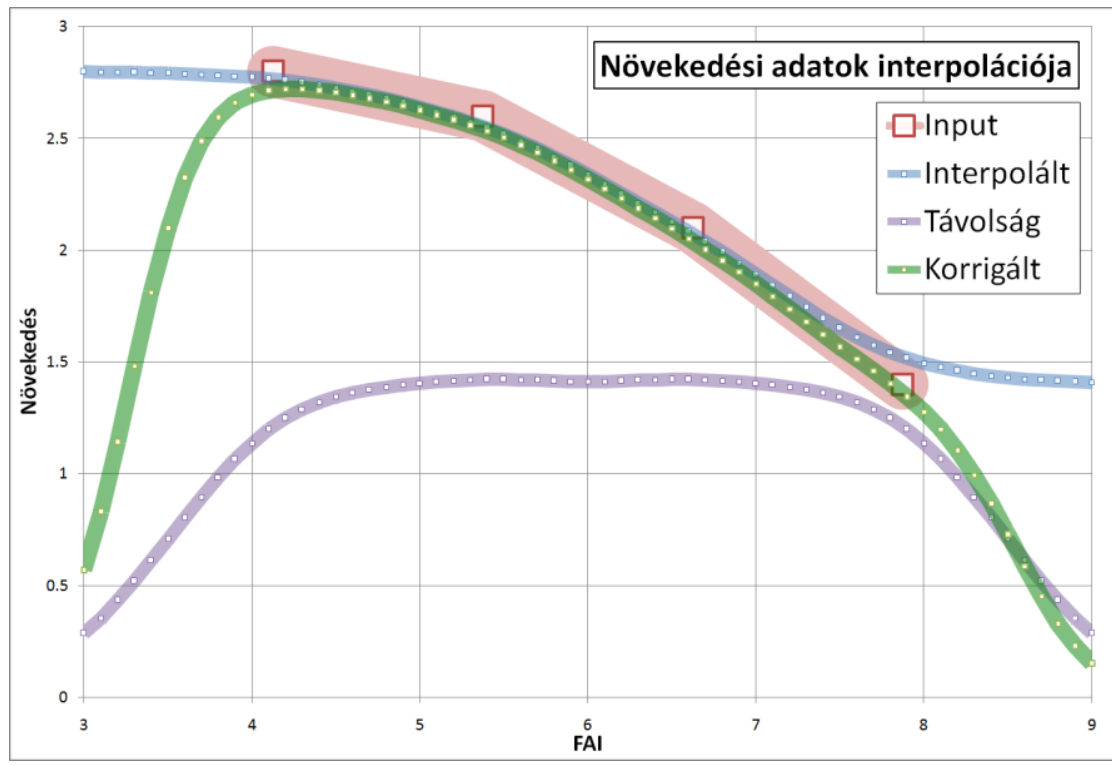

4. ábra: Növekedési adatok interpolációja (kék) egy jellemző (FAl) alapján, valamint korrigált interpolációja (zöld) a távolság (lila) segítségével a KTT példáján.

Figure 4: Interpolation of Sessile Oak growth data (blue) for one parameter (FAl), corrected interpolation (green) with the usage of distance (purple). 
Mivel a Járó-tábla csak ott tartalmaz bejegyzést, ahol egy fafaj erdészeti szempontból javasolt (például bükk fafaj csak bükkös klímában szerepel), ezért az interpolált 5 változós felületet a távolság függvénnyel (4. ábra, Távolság görbe) korrigálni kellett, hogy a hiányzó adatok esetében a felület a nulla növekedéshez közelítsen (4. ábra, Korrigált görbe). A képletben az r konstans a korrekciós távolságkernel szélességét definiálja:

$$
k_{c}(T)=\frac{f_{c}(T)}{w_{c}(T)}\left(1-e^{r f_{c}(T) w_{c}(T)^{2}}\right)
$$

A módszer célállományonként súlyoz, és csak a tanításra használt adatsoroktól való távolságszámítás és súlyozás után választja ki a legközelebbi öt célállományt. Ha a célállomány normalizált távolsága termőhelytípus-változat térben egy adott küszöbértéken kívül van, vagy ha a célállomány számított növekedése egy másik küszöbértéknél kisebb, akkor ez a célállomány nem fog szerepelni a kimeneti adatsorban.

\section{EREDMÉNYEK}

A módszer elsődleges kimenete egy lista minden erdészeti szempontból fontos, a jelenben és a jövőben valószínűsíthető termőhelytípus-változatra, amely tartalmazza a legközelebbi öt vagy kevesebb célállományt, azok várható növekedését számszerüsitve, valamint zárójelben egy egész számot, hogy a növedékbecslés hány közeli adatsor alapján történt (1. táblázat).

A módszert felkészítettük egy ötödikként belépő sztyep klímára történő becslésekre is. Erre a klímára a fafajok egyes klímaosztályokra adott válaszgörbéiböl indultunk ki és a bevezetett korrekciós függvény segítségével extrapoláltuk a növekedés értékeket. Ha az extrapoláció eredménye egy választott küszöbérték alatti (<1), vagy a normalizált távolság túlságosan nagy, akkor azt a termőhelytípus-változatot erdősítésre alkalmatlannak tartja a módszer.

A tanulási és növedék becslési módszer pontossági vizsgálatához az adatsort két részre osztottuk. A többletvízhatástól-független termöhelyeken a Járó-tábla bejegyzéseinek $50 \%$ át tanításra, a másik 50\%-ot pedig tesztelésre használtuk. A tesztelés során az öt paraméter alapján számított növekedési értékek és a referencia növekedések közötti átlagos eltérésre +0,01 érték adódott, az eltérések szórására pedig 0,35-öt kapunk, ami a 1; 2; 3 értékeket figyelembe véve jónak mondható. 
1. táblázat: Gépi tanulási módszer kimenetének részlete.

Table 1: Part of the output of the machine learning method.

\begin{tabular}{|c|c|c|c|c|c|c|c|c|}
\hline $\begin{array}{l}\text { Hidroló- } \\
\text { gia }\end{array}$ & $\begin{array}{c}\text { Genetikai } \\
\text { talaj- } \\
\text { típus }\end{array}$ & $\begin{array}{l}\text { Termő- } \\
\text { réteg }\end{array}$ & $\begin{array}{l}\text { Fizikai talaj- } \\
\text { féleség }\end{array}$ & B & GYT & CS-KTT & ESZTY & SZTY \\
\hline TVFLEN & LHE & MÉ & $\mathrm{H}$ & $\begin{array}{c}\text { KST } 2.0(4) \\
\text { FRNY } 1.7 \text { (3) } \\
\text { KTT } 2.3(4) \\
\text { A } 2.4(4)\end{array}$ & \begin{tabular}{|c} 
KST $1.9(9)$ \\
KTT $2.4(7)$ \\
FRNY $2.2(7)$ \\
A $2.5(9)$ \\
CS $2.0(3)$
\end{tabular} & $\begin{array}{c}\text { KST } 1.8(12) \\
\text { FRNY } 2.2(10) \\
\text { KTT } 2.4(8) \\
\text { A } 2.4(10) \\
\text { CS } 2.0(4)\end{array}$ & $\begin{array}{c}\text { KST } 1.7(8) \\
\text { FRNY } 2.2(7) \\
\text { A } 2.3(6) \\
\text { KTT 2.3 (4) }\end{array}$ & $\begin{array}{l}\text { KST } 1.4 \text { (3) } \\
\text { FRNY } 1.7 \text { (3) }\end{array}$ \\
\hline TVFLEN & LHE & MÉ & V & $\begin{array}{c}\text { KST } 2.6(6) \\
\text { FRNY } 2.3(3) \\
\text { KTT } 2.7 \text { (4) } \\
\text { B } 2.7(4) \\
\text { MK } 2.0 \text { (3) }\end{array}$ & $\begin{array}{c}\text { KST } 2.4(13) \\
\text { FRNY } 2.7(7) \\
\text { KTT } 2.7(8) \\
\text { A } 1.5(1) \\
\text { MK } 2.3 \text { (4) }\end{array}$ & $\begin{array}{c}\text { KST } 2.2(15) \\
\text { FRNY } 2.8(10) \\
\text { KTT } 2.7(9) \\
\text { A } 2.3(1) \\
\text { CS } 2.5(2)\end{array}$ & $\begin{array}{c}\text { KST } 2.2(10) \\
\text { FRNY } 2.7 \text { (7) } \\
\text { KTT } 2.7(4) \\
\text { A } 1.2(1) \\
\text { NNY } 2.6(3)\end{array}$ & $\begin{array}{c}\text { KST } 2.1 \text { (4) } \\
\text { FRNY } 2.3 \text { (3) } \\
\text { NNY } 1.4 \text { (2) }\end{array}$ \\
\hline
\end{tabular}


Erdőállomány adattár (2012-es állapot) erdőrészleteiben az erdészeti klímaosztály lecserélhető a klímamodellekből számított értékekre. Ehhez előbb a klímamodellekből a 30 éves időszakokra le kellett válogatni a havi hőmérsékletátlagokat és havi csapadékösszegeket, amelyekből az időszak átlagos FAl értékei, majd ebböl az erdészeti klímaosztály meghatározható minden erdőrészletre.

A gépi tanulási módszer valamennyi erdőrészletre tud javasolni a múlt és a jövő különböző időszakaira célállomány típust és növekedést. A növekedés értékek nem csak az 1,2 és 3 értékeket, hanem köztes értékeket is fel tudnak venni (tizedes törtek). A módszerrel két időszakot hasonlítottunk össze térképek segítségével: 1981-2010 és 2041-2070. Az 5. és 6. ábra a két időszakra a módszer által javasolt célállománytípusok földrajzi elhelyezkedését, míg a 7. és 8. ábra a célállományok növekedésnek térképeit mutatja. A térképek jól szemléltetik a várható változásokat.

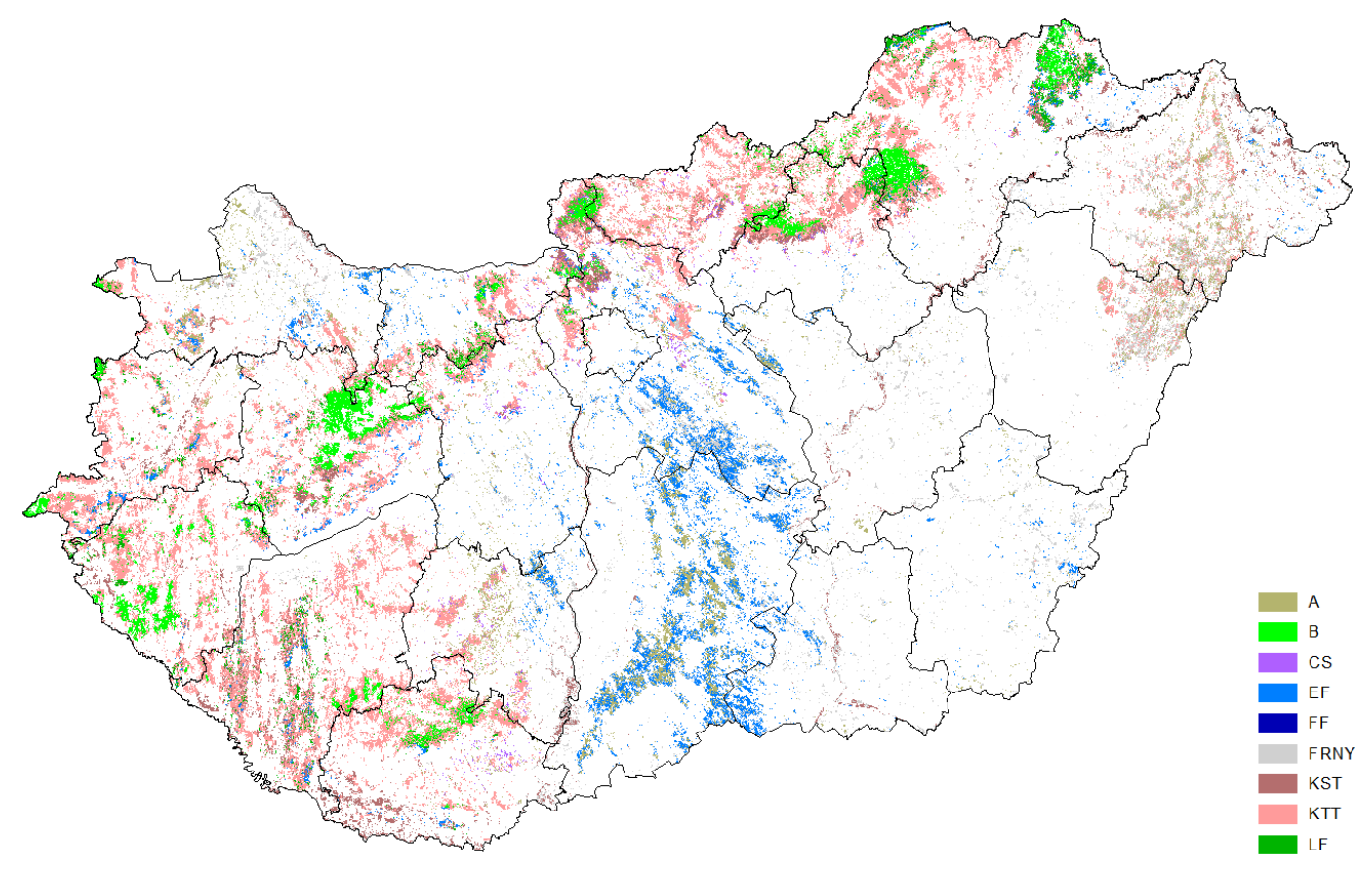

5. ábra: Módszer által javasolt célállománytípusok az 1981-2010 időszakban.

Figure 5: Targeted stands for 1981-2010 period proposed by the method. 


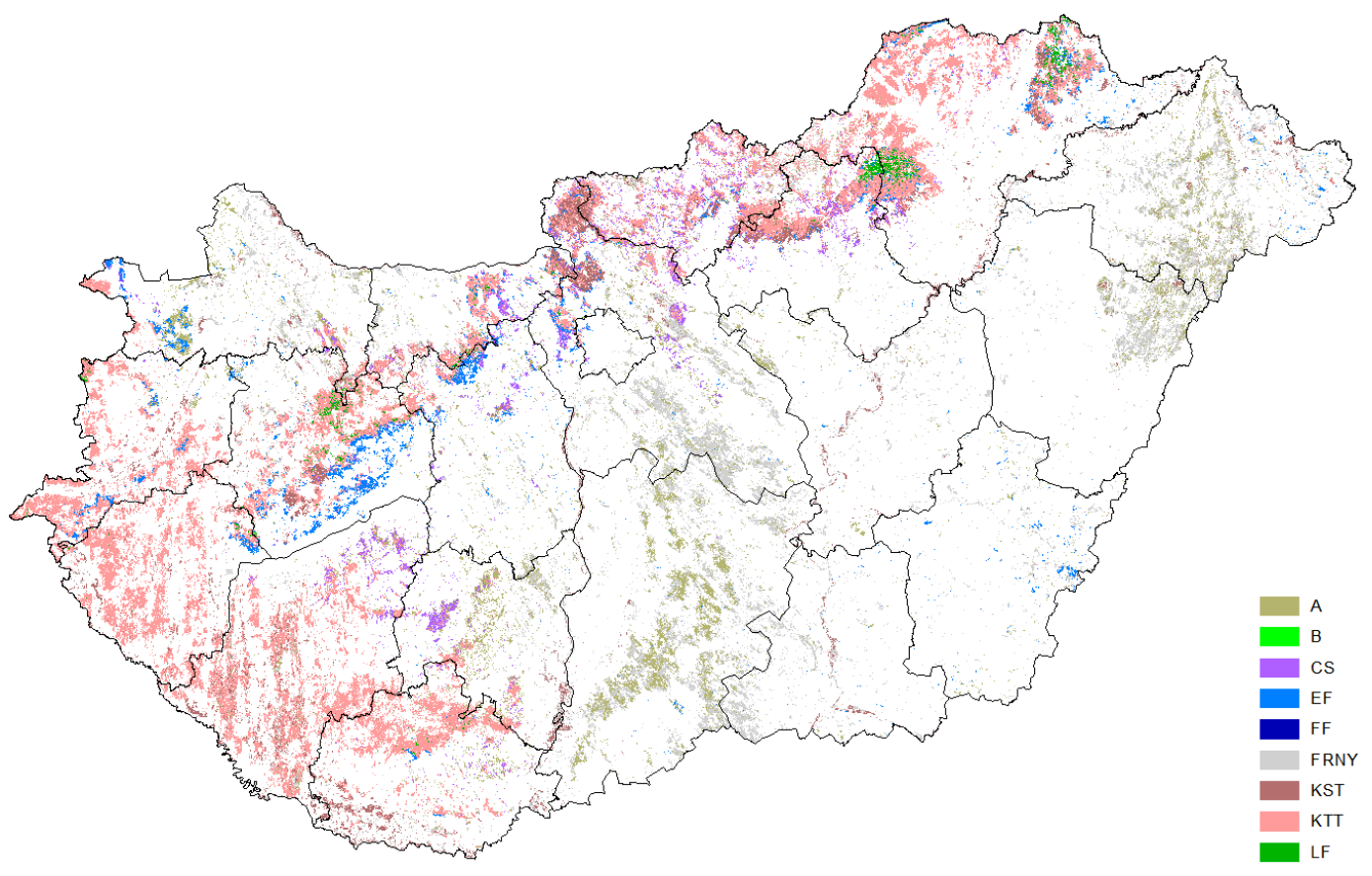

6. ábra: Módszer által javasolt célállománytípusok a 2041-2070 időszakban.

Figure 6: Targeted stands for 2041-2070 period proposed by the method.

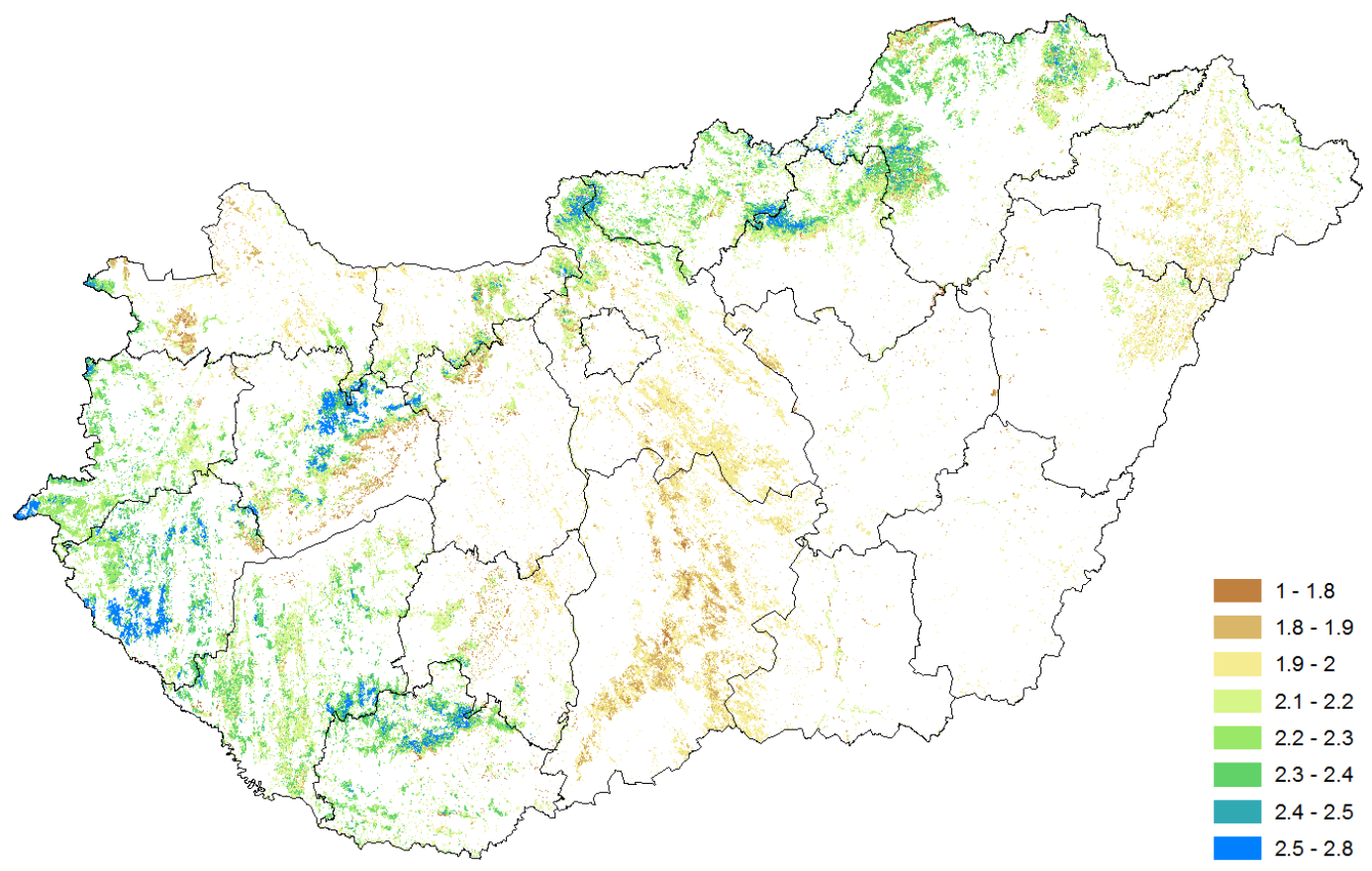

7. ábra: Módszer által javasolt célállományok növekedése az 1981-2010 időszakban.

Figure 7: Growth rate of targeted stands for 1981-2010 period proposed by the method. 


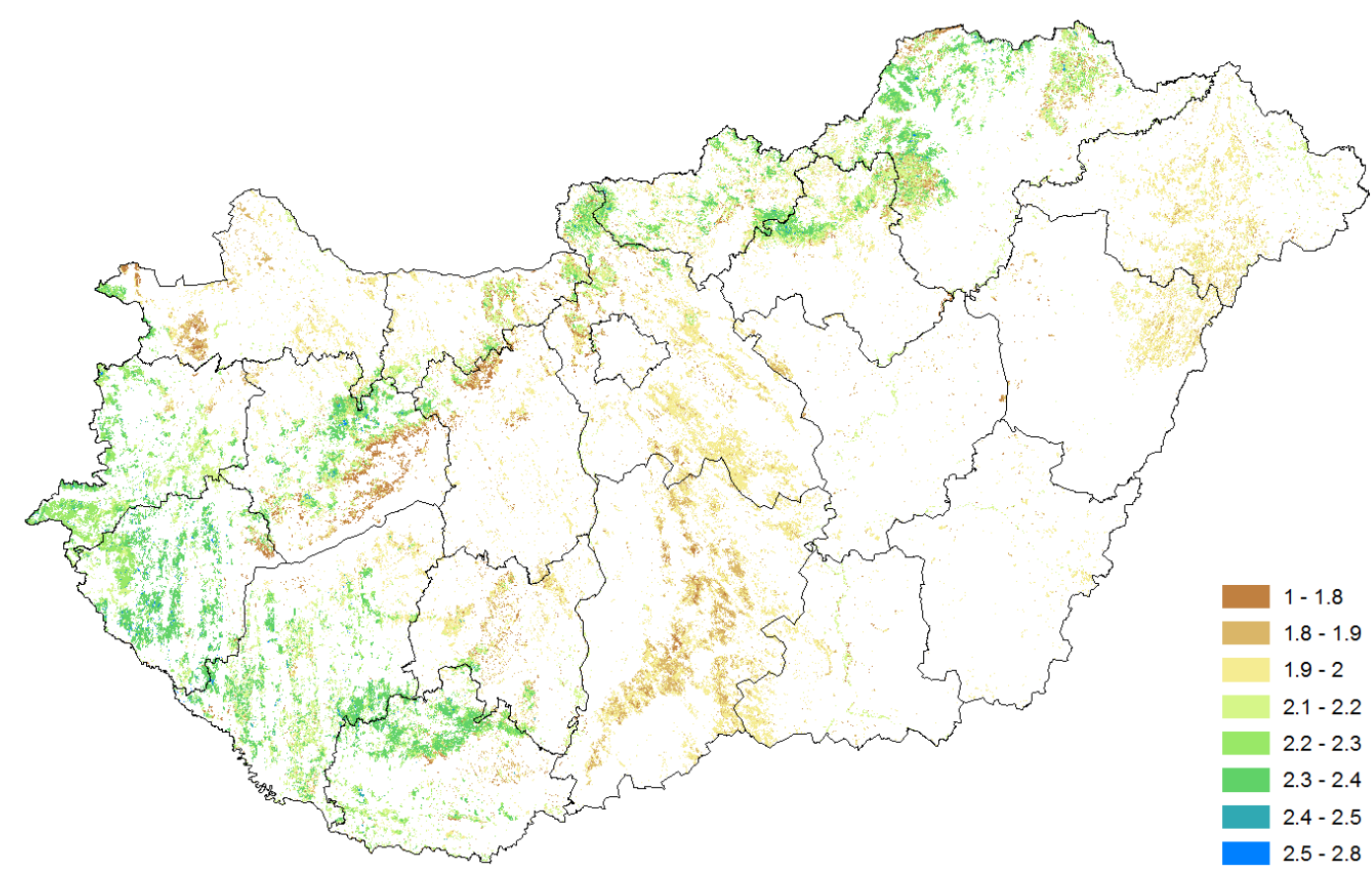

8. ábra: Módszer által javasolt célállományok növekedése a 2041-2070 időszakban.

Figure 8: Growth rate of targeted stands for 2041-2070 period proposed by the method.

\section{ÖSSZEFOGLALÁS}

Az eljárás fejlesztése több körben történt, az egyes kimeneti adatsorok részletes elemzése alapján. A kimeneti adatsorokat szakemberekkel vitattuk meg. Különösen a fafajonkénti küszöbértékek igényeltek alapos elemzést. A kifejlesztett és megvitatott táblázatot szakértői konszenzus után építjük be az eDTR végleges változatába.

\section{FELHASZNÁLT IRODALOM}

Balogh L., Kovács G. \& Tímár G. 2005: Az egyes termőhelytípus-változatokon alkalmazható célállományok. Állami Erdészeti Szolgálat, Budapest.

Berki I., Rasztovits E., Móricz N. \& Mátyás Cs. 2009: Determination of the drought tolerance limit of beech forests and forecasting their future distribution in Hungary. Cereal Research Communications 37: 613-616. DOI: 10.1556/CRC.37.2009.Suppl.4

Czimber K. \& Gálos B. 2016: A new decision support system to analyse the impacts of climate change on the Hungarian forestry and agricultural sectors. Scandinavian Journal of Forest Research 31: 664-673. DOI: 10.1080/02827581.2016.1212088 
Falcão A. \& Borges J.G. 2005: Designing decision support tools for Mediterranean forest ecosystems management: a case study in Portugal. Annals of Forest Science 62: 751-760. DOI: 10.1051/forest:2005061

Führer E. 2010: A fák növekedése és a klíma. Klíma-21 Füzetek 61: 98-107.

Führer E., Horváth L., Jagodics A., Machon A. \& Szabados I. 2011: Application of a new aridity index in Hungarian forestry practice. Időjárás 115: 103-118.

Gálos B., Führer E., Czimber K., Gulyás K., Bidló A., Hänsler A., et al. 2015: Climatic threats determining future adaptive forest management - a case study of Zala County. Időjárás 119(4): 425-441.

Mátyás Cs. \& Czimber K. 2000: Zonális erdőtakaró mezoklíma szintű modellezése: lehetőségek a klímaváltozás hatásainak elörejelzésére. In: Tar K. (ed): III. Erdő és Klíma Konferencia. DE-TTK, Debrecen, 83-97.

Mátyás Cs. \& Czimber K. 2004: A zonális zárt erdőtakaró alsó határának klímaérzékenysége Magyarországon. In: Mátyás Cs. \& Vig P., (eds): Erdő és Klíma IV. Nyugat-Magyarországi Egyetem, Sopron, 35-44.

Ray D. 2001: Ecological site classification decision support system. Version 1.7. Edinburgh: Forestry Commission.

Reynolds K.M., Twery M., Lexer M.J., Vacik H., Ray D., Shao G., et al. 2008: Decision Support Systems in Forest Management. In: Burstein F. \& Holsapple C. (eds): Handbook on Decision Support System 2. International Handbooks on Information Systems Series, Springer-Verlag Berlin Heidelberg, 499-534. DOI: 10.1007/978-3-540-48716-6

Rosenblatt M. 1956: Remarks on Some Nonparametric Estimates of a Density Function. The Annals of Mathematical Statistics 27(3): 832-837. DOI: 10.1214/aoms/1177728190

Silverman B.W. 1986: Density Estimation for Statistics and Data Analysis. Routledge, New York.

Vacik H., Lexer M.J., Rammer W., Seidl R., Hochbichler E., Strauss M., et al. 2010: ClimChAlp - a web based decision support system to explore adaptation options for silviculture in secondary Norway spruce forests in Austria. In: Falcao A. \& Rosset C. (eds): Proceedings of the Workshop on Decision Support Systems in Sustainable Forest Management, Lisbon.

Érkezett: 2018. május 4.

Közlésre elfogadva: 2018. május 29. 